\title{
ETHNOMATHEMATICA DALAM PEMBELAJARAN MATEMATIKA (PEMBELAJARAN BILANGAN DENGAN MEDIA BATIK MADURA, TARI KHAS TRENGGAL DAN TARI KHAS MADURA)
}

\author{
Dyah Worowirastri Ekowati \\ Dian Ika Kusumaningtyas \\ Nawang Sulistyani \\ Pendidikan Guru Sekolah Dasar, Universitas Muhammadiyah Malang \\ e-mail:dyah_umm@yahoo.com
}

\begin{abstract}
Cultural-based mathematics learning is a model of learning approach that prioritizes students' activities with a variety of cultural backgrounds, which are known as ethnomathematica. In this article will be elaborated mathematical activities that use cultural background. Therefore, this paper will describe a) how the application of ethnomathematica in mathematics learning, b) how the number of learning with batik madura, typical trenggal dance and typical madura dance.
\end{abstract}

\section{Keyword: learning mathematics, batik madura, dance typical trenggal, dance typical madura}

\begin{abstract}
Abstrak: Pembelajaran matematika berbasis budaya merupakan suatu model pendekatan pembelajaran yang lebih mengutamakan aktivitas siswa dengan berbagai ragam latar belakang budaya yang dimiliki, yang selanjutnya dikenal dengan ethnomathematica. Dalam artikel ini akan dijelas aktivitas matematika yang menggunakan latar belakang budaya. Oleh karenanya, makalah ini akan menjabarkan a) Bagaimana penerapan ethnomathematica dalam pembelajaran matematika, b) Bagaimana pembelajaran bilangan dengan media batik madura, tari khas trenggal dan tari khas madura.
\end{abstract}

Kata Kunci: ethnomathematica, pembelajaran matematika, batik madura, tari khas trenggal, tari khas madura

\section{PENDAHULUAN}

Kurikulum 2013 untuk tingkat sekolah dasar (SD) serta sederajat (MI) telah diberlakukan mulai tahun ajaran 2013/2014. Hal ini sejalan dengan permendikbud nomor 67 tahun 2013 perihal kompetensi dasar serta susunan kurikulum SD/MI yang disampaikan oleh Badan Standar Nasional Pendidikan (BNSP). Susunan kurikulum 2013 terdiri dari kompetensi inti serta kompetensi dasar (KD). Sebelumnya kurikulum yang berlaku yaitu kurikulum KTSP yang berubah menjadi kurikulum 2013. Pada kurikulum 2013 ini, pada awal pemberlakuannya di SD melaksanakan pembelajaran tematik yang meliputi bidang studi IPA, IPS, PKn, Bahasa Indonesia dan Matematika. Namun seiring perkembangannya, pada tahun 2017 ini, bidang studi matematika berdiri sendiri dan tidak ikut dalam pembelajaran tematik. Sesuai dengan
Permendikbud No 24 tahun 2016 tentang kompetensi dasar mata pelajaran di jenjang pendidikan dasar dan menengah yang menyatakan bahwa pembelajaran matematika dan PJOK sebagai mata pelajaran terpisah mulai kelas IV SD/MI. Oleh karenanya, penguasaan pembelajaran matematika para calon guru lebih ditekankan sebagai konsep yang terpisah dari pembelajaran tematik.

Pada pelaksanaan pembelajaran matematika, konsep matematika dikenal dengan penguasaan rumus-rumus. Berdasarkan hasil evaluasi dari pembelajaran di kelas dalam 10 tahun terakhir. Sebagian besar mahasiswa memaknai matematika melalui keabstrakannya saja. Matematika dipandang bukan sebagai aktivitas dalam kehidupan sehari-hari. Berdasarkan kegiatan pengabdian di sekolah Muhammadiyah mulai tahun 2008-2014 ini, menyatakan materi yang dirasa paling sulit oleh para guru adalah materi 
matematika. Sebagian besar kesulitan dalam menyajikan aktivitas matematika. Sebagian besar lagi kesulitan dalam memahami konsep dasar matematika.

Sebagai tenaga profesional, Guru menjadi salah satu penentu kualitas pembelajaran di sekolah serta mampu menyesuaikan dengan perkembangan zaman. Kualitas Guru diawali dengan penyiapan calon Guru yang berkualitas. Penyiapan calon guru yang berkualitas diawali dengan peningkatan kualitas pembelajaran yang dilakukan oleh para calon Guru tersebut. Program Studi PGSD sebagai anak bungsu FKIP memiliki semangat untuk terus meningkatkan kualitas pembelajaran.

Secara tidak langsung, para calon Guru harus dibekali kemampuan matematika yang kuat, kemampuan menyajikan pembelajaran matematika yang bermakna serta didukung dengan pembiasaan menggunakan media pembelajaran yang memadai. Pada akhirnya diharapkan pemahaman siswa terhadap konsep Matematika akan meningkat. Kebutuhan pembelajaran matematika di atas diperkuat dengan kebutuhan tahap perkembangan siswa SD yaitu operasional konkrit. Pembelajaran matematika harus dilakukan sekonkrit mungkin, konkrit bagi siswa bukan bagi Guru. Jembatan antara keabstrakan matematika menuju aktivitas matematika yang konkrit bagi siswa menjadi sangat penting. Perubahan pola pembelajaran matematika harus dimulai sejak dini. Dimulai dari proses belajar mengajar yang digunakan untuk membekali calon Guru. Salah satu cara mengkonkritkan pembelajaran matematika menggunakan kearifan lokal atau yang lebih dikenal sebagai ethnomathematica. Dimana ethnomathematica merupakan pembelajaran tentang matematika yang menggunakan perspektif budaya dimana aktivitas matematika muncul dengan memahami penalaran dan sistem matematika yang ada pada budaya yang digunakan. Etnomatematika dilakukan dengan menggunakan konsep matematika secara luas yang terkait dengan berbagai aktivitas matematika. Aktivitas yang dilakukan meliputi aktivitas mengelompokkan, berhitung, mengukur, merancang bangunan atau alat, bermain, menentukan lokasi, dan lain sebagainya. Aktivitas matematika yang biasanya dianggap abstrak oleh siswa menjadi lebih konkrit dengan dikaitkan dengan unsur budaya lokal. Budaya lokal yang dimaksud diantaranya adalah permainan tradisional. Makalah ini akan menjabarkan a) Bagaimana penerapan ethnomathematica dalam pembelajaran matematika, b) Bagaimana pembelajaran bilangan dengan media batik madura, tari khas trenggal dan tari khas madura.

\section{Penerapan ethnomathematica dalam pembelajaran matematika}

Pembelajaran berbasis budaya merupakan suatu model pendekatan pembelajaran yang lebih mengutamakan aktivitas siswa dengan berbagai ragam latar belakang budaya yang dimiliki, diintegrasikan dalam proses pembelajaran bidang studi tertentu, dan dalam penilaian hasil belajar dapat menggunakan beragam perwujudan penilaian. Selanjutnya pembelajaran ini dikenal sebagai ethnomathematica. Pembelajaran berbasis budaya dibagi menjadi 3 hal yaitu belajar tentang budaya, belajar dengan budaya, dan belajar melalui budaya.

Pembelajaran berbasis budaya harus memperhatikan empat hal, yaitu substansi dan kompetensi bidang ilmu/bidang studi, kebermaknaan dan proses pembelajaran, penilaian hasil belajar, serta peran budaya. Pembelajaran berbasis budaya lebih menekankan tercapainya pemahaman yang terpadu (integrated understanding) dari pada sekedar pemahaman mendalam(inert understanding). Proses penciptaan makna melalui proses pembelajaran berbasis budaya memiliki beberapa komponen, yaitu tugas yang bermakna, interaksiaktif, penjelasan dan penerapan ilmu secara kontekstual, dan pemanfaatan beragam sumber belajar (diadaptasi dari Brooks \& Brooks,1993, dan Krajcik, Czerniak Berger,1999).

Salah satu pendekatan yang sedang berkembang saat ini adalah pembelajaran berbasis budaya. Kegiatan pembelajaran diharapkan tidak hanya pemahaman konsep tetapi juga memahami budaya lokal yang ada. Budaya lokal yang ada, dapat digunakan 
sebagai sarana penyampaian dalam pembelajaran. Salah satu penerapannya yaitu pada pendekatan etnomatematika (Ethnomathematics). Etnomatematika diperkenalkan pertama kali pada tahun 1977 oleh D'Ambrosio, seorang matematikawan Brasil. Penjelasan mengenai etnomatematika menurut D'Ambrosio (dalam Wahyuni, dkk, 115: 2013) yaitu menyatakan bahwa ethnomathematics adalah studi tentang matematika yang memperhitungkan pertimbangan budaya dimana matematika muncul dengan memahami penalaran dan sistem matematika yang mereka gunakan.

Kajian etnomatematika dalam pembelajaran matematika mencakup segala bidang: arsitektur, tenun, jahit, pertanian, tarian tradisional, kain batik, hubungan kekerabatan, ornamen, dan spiritual dan praktik keagamaan sering selaras dengan pola yang terjadi di alam atau memerintahkan sistem ide-ide abstrak. Sedangkan menurut Barton (dalam Wahyuni, dkk, 115: 2013), ethnomathematics mencakup ide-ide matematika, pemikiran dan praktik yang dikembangkan oleh semua budaya. Ethnomathematics juga dapat dianggap sebagai sebuah program yang bertujuan untuk mempelajari bagaimana siswa untuk memahami memahami, mengartikulasikan, mengolah, dan akhirnya menggunakan ide-ide matematika, konsep, dan praktek-praktek yang dapat memecahkan masalah yang berkaitan dengan aktivitas sehari-hari mereka.

\section{METODE PENELITIAN}

Penelitian ini menggunakan model penelitian tindakan kelas dengan model spiral dari Kemmis dan Taggart yang merupakan alur pelaksanaan tindakan yang berlangsung dalam siklus. Siklus terdiri atas perencanaan, pelaksanaan tindakan, observasi, dan refleksi. Menurut (Suharsimi, 2006: 92) hubungan antara keempat komponen tersebut menunjukkan suatu siklus atau kegiatan berulang. Karena "siklus" inilah yang menjadi salah satu ciri utama dari penelitian tindakan, yaitu bahwa penelitian tindakan harus dilaksanakan dalam bentuk siklus, bukan hanya satu kali intervensi saja.
Fokus pembelajaran pada siklus I adalah untuk meningkatkan pemahaman mahasiswa terhadap konsep matematika. Sedangkan siklus II mengacu pada siklus I, akan tetapi lebih ditekan pada kemahiran prosedural dan algoritma melalui soal cerita yang dikemas dalam aktivitas matematika. Setiap aktivitas matematika selanjutnya didokumentasikanyang nantinya disebut draf bahan ajar matematika berbudaya.

\section{Prosedur Pengumpulan Data}

1. Observasi Aktivitas Siswa

Observasi dilakukan untuk mengamati aktivitas siswa selama proses pembelajaran berlangsung. Observer tinggal memberi tanda chek ( $\square$ ) pada deskriptor yang muncul kemudian menuliskan skor tiap indikator sesuai dengan pedoman penskoran pada lembar observasi.

2. Tes Hasil Belajar

Tes berfungsi untuk mengukur pemahaman konsep matematika selama mengikuti pembelajaran. Data hasil belajar siswa diperoleh dari hasil tes tertulis yang diberikan kepada siswa pada akhir pembelajaran.

\section{Format Wawancara}

Format wawancara disusun berisi pertanyaan-pertanyaan yang akan disampaikan pada saat wawancara dilakukan dengan subjek penelitian, yaitu siswa yang telah ditetapkan. Format wawancara disusun berdasarkan aspekaspek yang akandiketahui melalui wawancara dan disesuaikan dengan butir-butir soal tes. Indikator-indikator yang dikembangkan dalam format wawancara diharapkan dapat, mengungkap lebih banyak pemahaman konsep matematika

\section{HASIL DAN PEMBAHASAN}

\section{Pembelajaran bilangan dengan media batik madura, tari khas trenggal dan tari khas madura}

Ethnomathematics dilakukan dengan menggunakan konsep matematika secara luas yang terkait dengan berbagai aktivitas matematika. Aktivitas yang dilakukan meliputi aktivitas mengelompokkan, berhitung, mengukur, merancang bangunan atau alat, bermain, menentukan lokasi, dan lain sebagainya. 
Aktivitas matematika yang biasanya dianggap abstrak oleh siswa menjadi lebih konkrit dengan diukaitkan dengan unsur budaya lokal. Seperti yang disampaikan oleh D'Ambrosio (1985) bahwa tujuan dari adanya ethnomathematics adalah untuk mengakui bahwa ada cara-cara berbeda dalam melakukan matematika dengan mempertimbangkan pengetahuan matematika yang dikembangkan dalam berbagai sektor masyarakat serta dengan mempertimbangkan cara yang berbeda dalam aktivitas mayarakat seperti cara mengelompokkan, berhitung, mengukur, merancang bangunan atau alat, bermain dan lainnya. Selain itu, di bawah ini akan dijelas Pembelajaran bilangan dengan media batik madura, tari khas trenggal dan tari khas madura. Alat dan bahan: (a) gambar kearifan lokal Batik Madura, Tari Turonggo Yakso dan Tari Bapang; (b) kertas buffalo; (c) bolpoin warna-warni; (d) printer; (e) gunting.

Langkah-langkah pembuatan media: (a) Cara Perbuatan: (1) buatlah beberapa contoh bilangan di Microsoft Word; (2) setelah di buat, siapkan bufallo lalu hasil beberapa contoh bilangan tersebut di print menggunakan printer; (3) siapkan gunting untuk menggunting kertas yang telah di print tadi; (4) selesai digunting, kartu bilangan siap digunakan; (b) Petunjuk Penggunaan Media: kartu bilangan yang sudah di gunting, di siapkan di meja secara acak-acakan dan setiap kelompok pada saat presentasi ke depan di tuntut untuk mencari kartu bilangan yang disediakan sesuai dengan jawaban yang diperolehnya; (c) langkah pembelajaran: (1) bentuklah kelas menjadi 5 kelompok dan berkumpul dengan kelompoknya masing-masing; (2) berikanlah selembar kertas mengerjakan soal yang dibuat kepada masing-masing kelompok; (3) setiap kelompok berdiskusi mengerjakan soal yang diterimanya serta membuat password masing-masing kelompok; (4) setelah selesai mengerjakan setiap kelompok maju ke depan mencocokkan jawaban dengan kartu yang telah disedikan lalu mempresentasikan hasil diskusinya; (5) setiap kelompok memperhatikan dan mencatat apa yang dijelasakan oleh setiap kelompok; (6) setelah dipresentasikan, setiap kelompok diajak bermain dengan diberikan soal kuis oleh pengkaji sebagai penguatan tentang materi bilangan; (7) ada saat soal kuis diberikan secara langsung, setiap kelompok harus aktif dan merebut jawaban yang telah diberikan oleh pengkaji.

\section{Media Pembelajaran Berbasis Kearifan Lokal}

Kartu Bilangan merupakan media visual. Kartu Bilangan ini adalah kartu sederhana yang dibuat untuk memudahkan pemahaman siswa dalam materi bilangan. Oleh karena itu, dalam kegiatan pembelajaran seorang guru harus bisa merancang media pembelajaran yang menarik. Fungsi dan manfaat media pembelajaran dalam kartu bilangan ini sangatlah penting dalam kegiatan belajar mengajar. Sangatlah sulit materi bilangan tersampaikan dengan baik tanpa melalui media pembelajaran yang tepat. Penggunaan media akan lebih efektif apabila diiringi dengan penggunaan metode pembelajaran. Salah satu metode yang sesuai dengan karakteristik siswa usia Sekolah Dasar yaitu metode bermain. Siswa akan memperoleh pengetahuan dan pengalaman yang bermakna dari proses pembelajaran yang mudah dan menyenangkan.

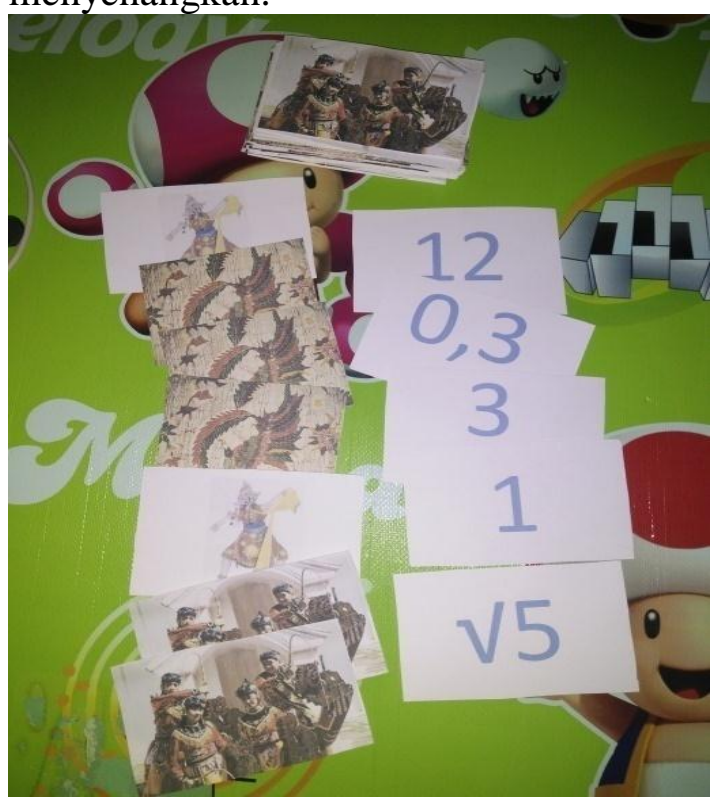

Kartu Bilangan terdiri dari banyak kartu yang dibuat berbentuk persegi panjang, didepan kartu tersebut terdapat bilangan-bilangan dan dibelakang kartu tersebut diberi gambar kearifan lokal sebagai tanda pengenal di daerah masingmasing. Media kartu bilangan berfungsi 
untuk menjelaskan tentang konsep dan selanjutnya memperdalam pemahaman siswa terhadap materi bilangan.

\section{SIMPULAN}

Ethnomathematics dilakukan dengan menggunakan konsep matematika secara luas yang terkait dengan berbagai aktivitas matematika. Aktivitas yang dilakukan meliputi aktivitas mengelompokkan, berhitung, mengukur, merancang bangunan atau alat, bermain, menentukan lokasi, dan sebagainya. Aktivitas matematika yang biasanya dianggap abstrak oleh siswa menjadi lebih konkrit dengan diukaitkan dengan unsur budaya lokal. Dalam makalah ini telah dijelaskan pembelajaran bilangan dengan media batik madura, tari khas trenggal dan tari khas madura. Kelebihan penggunanan media batik madura, tari khas trenggal dan tari khas madura dalam pembelajaran matematika menjelaskan tentang konsep dan selanjutnya memperdalam pemahaman siswa terhadap materi bilangan.

\section{DAFTAR PUSTAKA}

Ahimsa-Putra, S. 2008.. Ilmuwan Budaya dan Revitalisasi Kearifan Lokal: Tantangan Teoritis dan Metodologis. Yogyakarta: Fakultas Ilmu Budaya Universitas Gadjah Mada.

Budiwurianto, Arif. 2012. Pemanfaatan Potensi Lokal Budaya Intagible Jawa Timursebagai Dasar Model Pengembangan Content Pendidikan Budi Pekerti dan Softskill Pendidikan Dasar.

\section{D'Ambrosio, U. (1985).}

Ethnomathematics and its place in the history and pedagogy of mathematics. For the Learning of Mathematics, 5(1), 44-48.

D'Ambrosio. (1999). Literacy, Matheracy, and Technoracy: A Trivium for Today. Mathematical Thinking and Learning 1(2), 131 -153.
Haryono, Dyah, Erna. 2015. Matematika dasar untuk PGSD. Aditya media: Malang.

Karli, Hilda. 2009. Pembelajaran Tematik dan Pembelajaran Fragmented di Sekolah Dasar. Jurnal Pendidikan Penabur. No. 13/Tahun ke-8/Desember 2009.

Kemendikbud. 2016. Sumber Belajar Penunjang PLPG 2016 Mata Pelajaran/ Paket Keahlian Guru Kelas SD BAB I Bilangan. Kemendikbud: Jakarta.

Kemendikbud. 2016. Sumber Belajar Penunjang PLPG 2016 Mata Pelajaran/ Paket Keahlian Guru Kelas SD BAB II Aljabar. Kemendikbud: Jakarta

Kemendikbud. 2016. Sumber Belajar Penunjang PLPG 2016 Mata Pelajaran/ Paket Keahlian Guru Kelas SD BAB III Geometri. Kemendikbud: Jakarta.

Kemendikbud. 2016. Sumber Belajar Penunjang PLPG 2016 Mata Pelajaran/ Paket Keahlian Guru Kelas SD BAB IV Pengukuran. Kemendikbud: Jakarta.

Kemendikbud. 2016. Sumber Belajar Penunjang PLPG 2016 Mata Pelajaran/ Paket Keahlian Guru Kelas SD BAB $V$ Statistik. Kemendikbud: Jakarta.

Kemp, J. E, G. R. Morrison, \& S. M. Ross. 1994. Designing Effective Instruction. New York: Macmillan College Publishing Company.

Kemp, J. E, G. R. Morrison, \& S. M. Ross. 1994. Designing Effective Instruction. New York: Macmillan College Publishing Company.

Mungmachon, Roikhwanput. 2012. Knowledge and Local Wisdom: Community Treasure. International Journal of Humanities and Social Science. 
Vol. 2 No. 13. July 2012. 174181

Prastowo, Andi. 2012. Panduan Kreatif Membuat Bahan Ajar Inovatif. Yogyakarta: Diva Press.

Prastowo, Andi. 2013. Panduan Kreatif Membuat Bahan Ajar Inovatif. Yogyakarta: Diva Press.

Inda Rachmawati. 2014.Eksplorasi Etnomatematika Masyarakat Sidoarjo. Surabaya: UNESA.

Russell, James, D. 1973. Modular Instruction : A Guide to the Design, Selection, utilization and Evaluation of Modular Materials. Minnesota: Burgess Publishing Comp.

Smaldino, S. E, D. L. Lowther, \& J. D. Russel. 2011. Instructional Technology and Media for Learning: Teknologi Pembelajaran dan Media untuk Belajar. Terjemahan Arif Rahman. Jakarta: Kencana Prenada Media Group.

Soenaryo, Siti Fatimah dkk. 2015. Model Sinau-Wisata Berbasis Potesi Keunggulan Lokal sebagai Penunjang Pelaksanaan Pembelajaran Tematik Kurikulum 2013 bagi Sekolah Dasar Malang. Laporan Penelitian. Malang: UMM.

Vembriarto. 1985. Pengantar Pengajaran Modul. Yogyakarta : Yayasan Pendidikan Paramita.

Wagiran. 2012. Pengembangan Karakter Berbasis Kearifan Lokal Hamemayu Hayuning Bawana. Jurnal Pendidikan Karakter. Th. 2 No. 3. Oktober 2012. 329-339.

Wagiran. 2012. Pengembangan Karakter Berbasis Kearifan Lokal Hamemayu Hayuning Bawana. Jurnal Pendidikan Karakter. Th. 2 No. 3. Oktober 2012. 329-339.

Rachmawati, Inda. 2014. Eksplorasi Etnomatematika Masyarakat
Sidoarjo. Skripsi tidak dipublikasikan. Malang: UM.

Fitroh , Wahyu, dkk., 2015. Identifikasi pembelajaran matematika dalam tradisi melemang di Kabupaten Kerinci Provinsi Jambi. Prosiding Seminar Nasional Matematika dan Pendidikan Matematika UMS 2015, ISBN : 978.602.361.002.0. Surakarta: UMS. 